\title{
Sprawozdanie
}

\section{Konferencja Naukowa nt.: Czy i jak zmieniać Konstytucję RP?, Warszawa, 29 marca 2011 r.}

Konferencja została zorganizowana w Warszawie dnia 29 marca 2011 r. przez Instytut Spraw Publicznych. Podstawę do dyskusji stanowiła wydana przez Instytut publikacja pt. Ankieta konstytucyjna, nad której przygotowaniem nadzór merytoryczny objął prof. B. Banaszak (Uniwersytet Wrocławski). Książka, jak to określił witając wszystkich przybyłych prezes ISP, dr J. Kucharek (Instytut Spraw Publicznych), stanowi niejako wkład Instytutu do debaty na temat potrzeby i sposobów zmiany konstytucji RP. Debaty, która tak naprawdę toczy się od samego momentu uchwalenia Konstytucji w 1997 r. i która to już na etapie powstawania wywołała wiele kontrowersji. Wspomniana debata miała klika kluczowych i nagłośnionych w mediach momentów. W 2005 r. odbyła się dyskusja o tzw. IV RP. Wówczas partia Prawo i Sprawiedliwość przygotowała projekt zupełnie nowej konstytucji, która miała zastąpić obecnie obowiązującą. Kolejnym etapem była debata po wyborach z października 2007 r., w której skoncentrowano się nad kwestiami zasadniczymi dotyczącymi ustroju, podziału kompetencji między Prezydentem a Premierem. Równolegle przez ostatnie kilka lat toczyła się także dyskusja nad potrzebą zmian w konstytucji związanych z członkowstwem Polski w Unii Europejskiej. Jak podkreślił dr J. Kucharczyk przeprowadzona ankieta została skierowana do ekspertów - prawników konstytucjonalistów celem zebrania ocen obowiązujących rozwiązań ustrojowych i propozycji ich zmian. W ten sposób chciano nawiązać do najlepszych tradycji polskiego konstytucjonalizmu z okresu II Rzeczpospolitej.

Szerzej na ten temat wypowiedziała się w panelu historycznym, zatytułowanym Prace nad Konstytucjami II RP, dr K. Witkowska-Chrzczonowicz (Uniwersytet Mikołaja Kopernika w Toruniu), która przedstawiła przebieg prac nad ustawą zasadniczą odrodzonej Polski oraz wpływ przeprowadzonej w tamtych czasach ankiety konstytucyjnej na końcowy kształt rozwiązań ustrojowych przyjętych w konstytucji marcowej. Referentka podsumowując 
swoje wystąpienie, zaznaczyła, że politycy, jeśli już w ogóle skorzystali z dorobku ekspertów, to tylko z tego, który był dla nich korzystny politycznie, natomiast nie miało to nic wspólnego z jakąś koncepcją dyktowaną dobrem państwa. Drugim i zarazem ostatnim prelegentem w tej części spotkania był dr G. Kulka (Uniwersytet Wrocławski), który podkreślił, że problematyka koncepcji ustrojowych państwa polskiego z okresu II wojny światowej i doświadczenia $\mathrm{z}$ niej płynące uczą również dzisiaj. Według referującego, nie powinniśmy zapominać, iż żaden czynnik, nawet brak organu, bez którego istnienia nie można przeprowadzić zmiany konstytucji, nie powinien hamować jakiejkolwiek dyskusji wokół ustawy zasadniczej, aby w przyszłości nie stanowiła ona reliktu prawniczego, tylko konstytucję w pełnym tego słowa znaczeniu.

W dyskusji prof. A. Bałaban (Uniwersytet Szczeciński) przypomniał, że w trakcie prac nad konstytucją z 1997 r. również posłużono się ankietą konstytucyjną, kierując pytanie do 100 najwybitniejszych Polaków. W odpowiedzi na tą ankietę J. Giedroyc, powiedział wtedy, że nie ma potrzeby przygotowywania nowej konstytucji, ponieważ obowiązuje konstytucja kwietniowa. Profesor kończąc swoją wypowiedź stwierdził, że rzeczywiście z formalnego punktu widzenia nie było wyraźnego momentu uchylenia konstytucji z 1935 r., bo wszelkiego tego rodzaju akty władzy komunistycznej, niedemokratycznej, byłyby chyba mało wiarygodne z dzisiejszego punktu widzenia. Natomiast konstytucja demokratyczna tego nie zrobiła w 1997 r. Faktyczne przekazanie insygniów czy deklaracja rządu londyńskiego nie jest tutaj wystarczająca i nie może zastąpić uchylenia formalnego. Po tej wypowiedzi zaoponował prof. S. Gebethner (Szkoła Wyższa Psychologii Społecznej), który stwierdził, że konstytucji kwietniowej nie trzeba uchylać, bo ona nigdy nie obowiązywała z racji tego, że została uchwalona w sposób nielegalny. Natomiast podkreślił, że ustawa zasadnicza z 1935 r. przez ten przepis, że może obowiązywać również na obczyźnie stanowiła symbol jedności państwa i działania państwa podziemnego w czasach okupacji i to była jej największa rola. Można zatem uznać, że wszelkie dyskusje prawnicze w tej chwili czy ją uchylono czy też nie, nie mają najmniejszego znaczenia. Znaczenie ma to, jaką rolę odegrała w czasach okupacji.

W drugiej części konferencji, której przewodniczył prof. B. Banaszak, trzech uczestników przeprowadzonej przez ISP ankiety, tj. prof. A. Bałabana, prof. M. Chmaja (Uniwersytet Warmińsko-Mazurski) i prof. A. Szmy- 
ta (Uniwersytet Gdański) zaprezentowało swoje odpowiedzi do niej. Celem tego panelu było również, a raczej przede wszystkim, podsumowanie wyników Ankiety konstytucyjnej, którego dokonał prof. M. Wyrzykowski (Polska Akademia Nauk). Profesor rozpoczął od rozważań nad samym pytaniem „czy i jak zmieniać konstytucję” oraz przypomniał, że debata nad jakością uchwalonej w 1997 r. ustawy zasadniczej rozpoczęła się już nazajutrz po jej wejściu w życie i trwa nieprzerwanie przez ostatnie 14 lat. Zaznaczył jednak, że w latach 2010-2011 dało się zauważyć konstytucjonalizację życia publicznego, życia politycznego, co może tłumaczyć tak frontalne postawienie pytania przez organizatorów konferencji. Dzisiaj każdy powołuje się na konstytucję, ale to nic nowego, zawsze tak było. Profesor stwierdził, że mamy nasycenie myśleniem konstytucyjnym poważniejsze, głębsze. Źródłem koncepcji, która legła u podstaw ankiety konstytucyjnej, były próby zmiany ustroju państwa, zmiany ustroju III RP. Profesor zaznaczył również, że ankieta nie jest dla niego na tyle reprezentatywna, aby uznać ją za głos całego środowiska konstytucjonalistów, a jedynie za opinię tych autorów, którzy wzięli w niej udział. Profesor syntetycznie omówił kluczowe problemy poruszane przez uczestników ankiety.

Następnie głos zabrał prof. M. Chmaj, który przedstawił cechy idealnej według niego konstytucji. Skrytykował obszerność projektów zmieniających ustawę zasadniczą, zbyt dużą łatwość nowelizowania jej postanowień oraz niejasność norm. Z kolei prof. A. Bałaban wskazał, że alternatywą dla tak przygotowanej ankiety byłoby skierowanie do kierowników Katedr Prawa Konstytucyjnego prośby o wskazanie pięciu najważniejszych kwestii wymagających zmian w ustawie zasadniczej. Profesor podkreślił również, że obecnie mamy przesyt proponowanych zmian, które niekoniecznie wyszłyby polskiej ustawie zasadniczej na dobre. Referent dodał, że trwałość i funkcja prawna nie zależą od permanentnych nowelizacji, lecz szacunku dla samej konstytucji jako symbolu pewności prawa i trwałości państwa. Co ważniejsze, ta trwałość i pewność jest ważniejsza od samej konstytucji i może zostać osiągnięta także innymi metodami. Prof. A. Szmyt skupił swoją uwage na ocenie obecnie funkcjonujących w parlamencie projektów zmiany konstytucji, zwłaszcza w zakresie rozdziału europejskiego. Podkreślił jednak, że aktualnie nie mamy w Polsce dobrego momentu na zmianę ustawy zasadniczej. Profesor zwrócił się z prośba o nieużywanie rozróżnienia na zmianę częściową i całkowitą konstytucji. Według referenta zmiana zawsze może 
być tylko częściowa, stąd prawnik powinien mówić, albo że uchwalono konstytucję, albo że ją zmieniono.

Po wystąpieniach referentów tytułem uzupełnienia zabrał głos poseł K. Karski. Wiceprzewodniczący Nadzwyczajnej Komisji Konstytucyjnej, zajmującej się analizowanymi na konferencji czterema projektami zmiany ustawy zasadniczej, wzbogacił dyskusję o elementy praktyczne dotyczące zakresu pracy poczynionej na jej posiedzeniach. Zaznaczył, że na dobrą sprawę rozpatrywane są już tylko dwa z czterech projektów. Dodał, że wszyscy członkowie komisji mają świadomość, że kwestie europejskie wymagają nowelizacji. Przewodniczący Państwowej Komisji Wyborczej S. J. Jaworski z uznaniem przyjął wielokrotnie proponowane przez uczestników ankiety ukonstytucjonalizowanie Państwowej Komisji Wyborczej i wyposażenie jej w możliwość wydawania rozporządzeń, a co za tym idzie, usprawnienie jej organizacji. Na koniec tej części zabrał głos dr R. Balicki (Uniwersytet Wrocławski), który zaapelował, żeby stabilność konstytucji nie doprowadziła do jej stagnacji, konstytucja musi bowiem reagować na zmiany w społeczeństwie. Dr R. Balicki nie zgodził się z prof. A. Bałabanem, że rozpoczęcie dyskusji niesie za sobą swoiste niebezpieczeństwo. Dyskusja jest potrzebna, a obecnie jest jej stanowczo za mało, zwłaszcza wśród konstytucjonalistów, których to refleksja jest jak najbardziej pożądana ze względu na ich merytoryczne przygotowanie. Dr R. Balicki poruszył również kwestię powszechnych wyborów prezydenckich. Zaznaczył, że jako naród jesteśmy przyzwyczajeni do „magii prezydenta wszystkich Polaków”, co w dzisiejszej sytuacji faktycznej jest fikcją. Jest bowiem niemożliwym, żeby wybory prezydenckie mógł wygrać kandydat nie mający silnego poparcia politycznego, partyjnego.

Punktem wyjścia dla rozważań poczynionych w trzeciej części konferencji była zmiana konstytucji w zakresie przepisów europejskich wniesiona przez Prezydenta B. Komorowskiego, ale zainicjowana jeszcze w czasach, gdy pełnił funkcję Marszałka Sejmu, kiedy to stworzył grupę ekspertów dla przygotowania takiego projektu. Prof. M. Kruk-Jarosz (Polska Akademia Nauk) zwróciła uwagę na fakt, że przepisy konstytucyjne regulujące tą materię powstały bardzo dawno, kiedy Polska jeszcze nie należała do UE a sama Wspólnota nie miała pewności, w jakim kierunku będzie podążać. Po wyczerpującym wprowadzeniu przez przewodniczącą ostatniego panelu, głos zabrali prelegenci. 
Prof. P. Policastro (Uniwersytet Szczeciński) przewrotnie rozpoczął swoje wystąpienie od pytania, „co my jako kraj możemy zrobić, aby proces integracji europejskiej był jak najbardziej skuteczny”. Następnie zakreślił ogólną wizję dostosowania polskiego porządku konstytucyjnego do pewnych standardów europejskich. Z kolei prof. B. Makowicz skupił się na przedstawieniu rozwiązań niemieckich w zakresie dostosowania udziału izb parlamentarnych do uczestnictwa w procesie legislacyjnym Unii Europejskiej. Ostatni już referent, dr T. Milej (Uniwersytet w Kolonii), zaprezentował nieskuteczność procesu implementacji dyrektyw do porządku wewnętrznego w Polsce.

W dyskusji prof. A. Bałaban nie zgodził się z tezami dra T. Mileja. Ponadto zaproponował, żeby wytyczne w ustawie do rozporządzenia były fakultatywne, co uelastyczni konstrukcję rozporządzenia. Poseł K. Karski zaapelował, aby nie wyposażać rządu w kolejne instrumenty do implementacji prawa europejskiego. Problem sam się rozwiąże, jeżeli rząd zacznie efektywniej wykorzystywać możliwości, które już ma. Poseł nawiązał również do wystąpienia prof. B. Makowicza (Uniwersytet Europejski Viadrina), który mówił o możliwości wnoszenia skarg do ETS przez parlamenty krajowe w związku z naruszeniem zasady pomocniczości. Zgodził się z referentem i podkreślił, że nie budzi wątpliwości, że takie rozwiązanie powinno istnieć, także na wniosek mniejszości parlamentarnej. Dr K. Witkowska-Chrzczonowicz podkreśliła wagę prewencyjnej kontroli ratyfikowanych traktatów dotyczących prawa europejskiego.

Na koniec prof. B. Banaszak podsumował i zakończył konferencję.

Izabela Joanna Biśta (Uniwersytet Wrocławski) 